\title{
Prevalence of Gastrointestinal Helminthosis in Horses in and around Anand District (Gujarat)
}

\author{
Prakriti Singh $^{1 *}$, J.J. Hasnani ${ }^{1}$, P.V. Patel ${ }^{1}$, Namrata Singh ${ }^{2}$ and Adesh Kumar ${ }^{3}$ \\ ${ }^{1}$ College of Veterinary Science and A. H., Anand Agricultural University, Anand (Guj.), India \\ ${ }^{2}$ Animal husbandry department, Raigarh, India \\ ${ }^{3}$ IVRI, Izzatnagar, Bareilly, India \\ *Corresponding author
}

\begin{tabular}{|c|c|}
\hline & A B S T R A C T \\
\hline & \multirow{6}{*}{$\begin{array}{l}\text { Gastro intestinal helminthosis in horses are the serious health problem contributing to poot } \\
\text { body condition, reduced work out, poor reproductive performance and short life span } \\
\text { Objective is to study the prevalence of gastrointestinal helminths of horses. A total of } 247 \\
\text { faecal samples were collected from the horses. Faecal samples were brought to the } \\
\text { laboratory for further processing and examined for the presence of parasitic infection by } \\
\text { standard faecal sample examination method. A total of } 247 \text { faecal samples were collected } \\
\text { from Anand district out of which } 79 \text { faecal samples were found positive with the overal } \\
\text { prevalence of } 31.98 \% \text {. Various gastrointestinal helminths have been encountered during } \\
\text { the whole study period, viz. Strongylus spp. }(11.74 \%) \text {, Parascaris equorum }(8.91 \%) \\
\text { Oxyuris equi }(2.83 \%) \text {, Strongyloides westeri }(3.64 \%) \text {, Habronema spp. }(0.81 \%) \\
\text { Amphistome spp. }(1.21 \%) \text {, Anoplocephala spp. }(0.40 \%) \text { and Setaria equina }(2.43 \%) \text {. There } \\
\text { was statistically significant difference between monthwise and overall prevalence of } \\
\text { different gastrointestinal helminthosis. However, there was no statistical difference in the } \\
\text { season wise, agewise, sexwise and breedwise gastrointestinal helminthosis. Collection of } \\
\text { fresh faecal samples for processing, if delay in faecal sample collection it will leads to } \\
\text { hatching of eggs and contamination of faecal samples by another source. Gastrointestina } \\
\text { helminthosis is a common condition in horses. }\end{array}$} \\
\hline & \\
\hline $\begin{array}{l}\text { Prevalence, } \\
\text { Gastrointestinal } \\
\text { helminthosis, } \\
\text { Faecal samples }\end{array}$ & \\
\hline Article Info & \\
\hline $\begin{array}{l}\text { Accepted: } \\
\text { 04 March } 2019 \\
\text { Available Online: } \\
10 \text { April } 2019\end{array}$ & \\
\hline & \\
\hline
\end{tabular}

\section{Introduction}

The total number of horses and ponies in India as per 2012 Census is 0.62 million numbers. Population of horse in Gujarat state is 18264 as per $19^{\text {th }}$ livestock census, 2012 (1). The study was carried out in and around Anand district where horse and ponies population were 244. Equines are said to have the largest collection of parasites of all domestic livestock. These parasites cause damage to the animals both during the infection phase and then again after these larval stages have emerged and developed fully to adult parasites (2). As any other animal, equines are also vulnerable to a variety of diseases of biological origin, nutritional diseases or disorders and miscellaneous causes. Among which the most common entities leading to ill-health, 
suffering and early demise and finally death are infectious diseases and parasitism, which resulted in considerably reduced animals work output, reproductive performance and most of all their longevity (3). This study was carried out to determine the prevalence of gastrointestinal helminths according to faecal examination in horses in and around Anand District (Gujarat).

\section{Materials and Methods}

In this study a total of 247 faecal samples were collected from the horses brought to the Veterinary Clinical Complex (VCC), Department of Surgery and Radiology, College of Veterinary Science and A. H., AAU, Anand and the surrounding field areas. The month wise, season wise, age wise, sex wise, breed wise and overall prevalence were studied during the period. The samples were collected in small and clean sterilized polythene bags. The bags were numbered, ligated with rubber bands and were brought to the laboratory for further processing and examined for the presence of parasitic infection. For recording and findings of prevalence, faecal samples of horses were collected for the detection and identification of eggs of gastrointestinal helminths as per standard method (Fig. 1-7).

\section{Statistical analysis}

Chi square $\left(\chi^{2}\right)$ test was used for analysis of prevalence data. For applying $\chi 2$ test, IBM SPSS 20.0 software was used.

\section{Results and Discussion}

\section{Month wise prevalence}

The highest prevalence rate was observed in the month of August (43.48 \%) and lowest in the month of March (21.05\%) by examining faecal samples. A significant difference $(\mathrm{p}<$
0.05) was found regarding the monthwise prevalence of gastrointestinal helminthosis in horses. In this study higher prevalence occur in the months of August (43.48\%) followed by September (42.86\%), October $(36.84 \%)$ and July (35.48\%) (Table 1).

\section{Season wise prevalence}

The highest prevalence of gastrointestinal helminthosis was noticed in Monsoon followed by winter and lowest in summer. A total of 247 faecal samples were collected out of which 79 faecal samples were found positive with overall seasonal prevalence higher in Monsoon (14.98\%) followed by Winter $(9.31 \%)$ and lower in Summer (7.69\%). However, there was no significant difference $(p>0.05)$ in the overall seasonal prevalence of gastrointestinal helminthosis (Table 2, 3 and 4).

\section{Age wise prevalence}

The occurrence of gastrointestinal helminthosis was more frequently recorded in horses from 6-12 years followed by 12-18 year and lower in 1-6 years by examining faecal samples. A total of 247 faecal samples were collected, out of which 79 faecal samples were found positive with the age wise prevalence of $(33.96 \%)$ in 6-12 years, $(30.85 \%)$ in $12-18$ years and $(29.79 \%)$ in $1-6$ years. There was no significant difference $(\mathrm{p}>$ $0.05)$ in the agewise prevalence of gastrointestinal helminthosis in horses (Table $5)$.

\section{Sex wise prevalence}

Overall the higher prevalence of gastrointestinal helminthosis was noticed in female and lower in male by examining faecal samples. A total of 247 faecal samples were collected, out of which 79 faecal samples were found positive with the sexwise 
prevalence of $(33.04 \%)$ in female and $(31.11 \%)$ in male. No significant difference ( $>0.05$ ) was found regarding the sexwise prevalence of gastrointestinal helminthosis in horses (Table 6).

\section{Breedwise prevalence}

A total of 247 faecal samples were collected, out of which 79 faecal samples were found positive with the breedwise prevalence of $(33.66 \%)$ in Kathiawari followed by Marwari (32.14\%) and lowest in Non Descript (Sindhi, Thoroughbreed, Punjabi etc.) (29.03\%). There was no significant difference ( $>$ 0.05) regarding the breedwise prevalence of gastrointestinal helminthosis in horses (Table 7).

\section{Overall prevalence}

In this study for deriving prevalence rate, 247 faecal samples were collected out of which 79 faecal samples were found positive with overall prevalence rate of $(31.98 \%)$. A significant difference $(\mathrm{p}<0.05)$ was found regarding the overall prevalence of gastrointestinal helminthosis in horses. Various gastrointestinal helminths have been encountered during the whole study period, viz. Strongylus spp. (11.74\%), Parascaris equorum (8.91\%), Oxyuris equi (2.83\%), Strongyloides westeri. (3.64\%), Habronema spp. (0.81\%), Amphistome spp. (1.21\%), Anoplocephala spp. (0.40\%) and Setaria equina $(2.43 \%)$.

Prevalence of Strongylus spp. was found higher in August (21.74\%) and July (19.35\%) months. Prevalence of Parascaris equorum was found higher in August (17.39\%) and in September (14.28\%) months. Prevalence of Strongyloides westeri was consistently seen from August-16 to February-17 and higher in September $(9.52 \%)$ month. Habronema spp. were detected in May (5.55\%) and June $(4.35 \%)$ months. Anoplocephala spp. was found only in April month with prevalence of (4.55\%). Oxyuris equi and Amphistome spp. were also reported in the study period without any relation to the particular months. Setaria equina incidences were seen throughout years.

Table.1 Month wise prevalence of gastrointestinal helminthosis in horses by faecal examination

\begin{tabular}{|c|c|c|c|}
\hline Month & Total F/S examined & No. of positive & Percent prevalence (\%) \\
\hline March-16 & 19 & 4 & 21.05 \\
\hline April-16 & 22 & 6 & 27.27 \\
\hline May-16 & 18 & 4 & 22.22 \\
\hline June-16 & 23 & 5 & 21.74 \\
\hline July-16 & 31 & 11 & 35.48 \\
\hline August-16 & 23 & 10 & 43.48 \\
\hline September-16 & 21 & 9 & 42.86 \\
\hline October-16 & 19 & 7 & 36.84 \\
\hline November-16 & 17 & 6 & 35.29 \\
\hline December-16 & 21 & 7 & 33.33 \\
\hline January-17 & 16 & 5 & 31.25 \\
\hline February-17 & 17 & 5 & 29.41 \\
\hline Over all & 247 & 79 & 31.98 \\
\hline \multicolumn{2}{r}{$(\mathbf{p}<\mathbf{0 . 0 5}=$ significant $)$} & $(\mathbf{p}>\mathbf{0 . 0 5}=$ Non significant $)$ \\
\hline
\end{tabular}


Table.2 Prevalence of gastrointestinal helminthosis in particular season in horses by faecal examination

\begin{tabular}{|c|c|c|c|}
\hline Season & Total F/S examined & No. of positive & Percent prevalence (\%) \\
\hline $\begin{array}{c}\text { Summer } \\
\text { (March-June) }\end{array}$ & 82 & 19 & 23.17 \\
\hline $\begin{array}{c}\text { Monsoon } \\
\text { (July-Oct) }\end{array}$ & 94 & 37 & 39.36 \\
\hline $\begin{array}{c}\text { Winter } \\
\text { (Nov-Feb) }\end{array}$ & 71 & 23 & 32.39 \\
\hline Total & 247 & 79 & 31.98 \\
\hline \multicolumn{2}{|c|}{$\quad(\mathbf{p}<\mathbf{0 . 0 5}=$ significant) $(\mathbf{p}>\mathbf{0 . 0 5}=$ Non significant $)$} \\
\hline
\end{tabular}

Table.3 Season wise positive prevalence of gastrointestinal helminthosis in horses by faecal examination

\begin{tabular}{|c|c|c|c|}
\hline Season & Total F/S examined & No. of positive & $\begin{array}{c}\text { Percent prevalence } \\
(\mathbf{\%})\end{array}$ \\
\hline $\begin{array}{c}\text { Summer } \\
\text { (March-June) }\end{array}$ & 82 & 19 & 24.05 \\
\hline $\begin{array}{c}\text { Monsoon } \\
\text { (July-Oct) }\end{array}$ & 94 & 37 & 46.84 \\
\hline $\begin{array}{c}\text { Winter } \\
\text { (Nov-Feb) }\end{array}$ & 71 & 23 & 29.11 \\
\hline Total & 247 & 79 & 100 \\
\hline \multicolumn{3}{|c|}{$(\mathbf{p}<\mathbf{0 . 0 5}=$ significant $)(\mathbf{p}>\mathbf{0 . 0 5}=$ Non significant $)$} \\
\hline
\end{tabular}

Table.4 Overall seasonal prevalence of gastrointestinal helminthosis in horses by faecal examination

\begin{tabular}{|c|c|c|c|}
\hline Season & Total F/S examined & No. of positive & Percent prevalence (\%) \\
\hline $\begin{array}{c}\text { Summer } \\
\text { (March-June) }\end{array}$ & 82 & 19 & 7.69 \\
\hline $\begin{array}{c}\text { Monsoon } \\
\text { (July-Oct) }\end{array}$ & 94 & 37 & 14.98 \\
$\begin{array}{c}\text { Winter } \\
\text { (Nov-Feb) }\end{array}$ & 71 & 23 & 9.31 \\
\hline Total & 247 & 79 & 31.98 \\
\hline \multicolumn{3}{|c|}{$(\mathbf{p}<\mathbf{0 . 0 5}=$ significant) $(\mathbf{p}>\mathbf{0 . 0 5}=$ Non significant) } \\
\hline
\end{tabular}


Table.5 Age wise prevalence of gastrointestinal helminthosis in horses by faecal examination

\begin{tabular}{|c|c|c|c|}
\hline Age & Total F/S examined & No. of positive & $\begin{array}{c}\text { Percent } \\
\text { prevalence }(\%)\end{array}$ \\
\hline (1-6 year) & 47 & 14 & 29.79 \\
\hline (6-12 Year) & 106 & 36 & 33.96 \\
\hline (12-18 Year) & 94 & 29 & 30.85 \\
\hline Total & 247 & 79 & 31.98 \\
\hline \multicolumn{4}{|c|}{$\chi^{2}=0.274, p=0.872($ Non Significant $)$} \\
\hline \multicolumn{4}{|c|}{$(p<0.05=$ significant $)(p>0.05=$ Non significant $)$} \\
\hline
\end{tabular}

Table.6 Sex wise prevalence of gastrointestinal helminthosis in horses by faecal examination

\begin{tabular}{|c|c|c|c|}
\hline Sex & $\begin{array}{c}\text { Total F/S } \\
\text { examined }\end{array}$ & No. of positive & Percent prevalence (\%) \\
\hline Male & 135 & 42 & 31.11 \\
\hline Female & 112 & 37 & 33.04 \\
\hline Total & 247 & 79 & 31.98 \\
\hline \multicolumn{2}{|c|}{$\boldsymbol{\chi}^{\mathbf{2}}=\mathbf{0 . 0 6 3}, \mathbf{p}=\mathbf{0 . 8 0 3}$ (Non Significant) } \\
\hline
\end{tabular}

Table.7 Breed wise prevalence of gastrointestinal helminthosis in horses by faecal examination

\begin{tabular}{|c|c|c|c|}
\hline Breed & $\begin{array}{c}\text { Total F/S } \\
\text { examined }\end{array}$ & $\begin{array}{c}\text { No. of } \\
\text { positive }\end{array}$ & $\begin{array}{c}\text { Percent } \\
\text { prevalence } \\
(\%)\end{array}$ \\
\hline Kathiawari & 101 & 34 & 33.66 \\
\hline Marwari & 84 & 27 & 32.14 \\
\hline $\begin{array}{c}\text { Non Descript (Sindhi, } \\
\text { Thoroughbreed, Punjabi etc. })\end{array}$ & 62 & 18 & 29.03 \\
\hline Total & 247 & 79 & 31.98 \\
\hline \multicolumn{2}{|c|}{$\boldsymbol{\chi}^{\mathbf{2}=\mathbf{0 . 4}, \mathbf{p}=\mathbf{0 . 8 1 9} \text { (Non Significant) }}$} \\
\hline \multicolumn{2}{|c|}{$(\mathbf{p}<\mathbf{0 . 0 5}=\mathbf{s i g n i f i c a n t )}(\mathbf{p}>\mathbf{0 . 0 5}=$ Non significant) } \\
\hline
\end{tabular}


Table.8 Month wise prevalence of different gastrointestinal helminths in horses by faecal examination

\begin{tabular}{|c|c|c|c|c|c|c|c|c|c|c|}
\hline Month & $\begin{array}{l}\text { Total F/S } \\
\text { examined }\end{array}$ & $\begin{array}{l}\text { No. of } \\
\text { positive }\end{array}$ & $\begin{array}{c}\text { Strongylusspp. } \\
(\%)\end{array}$ & $\begin{array}{c}\text { Parascaris } \\
\text { equorum } \\
(\%)\end{array}$ & $\begin{array}{l}\text { Oxyuris } \\
\text { equi }(\%)\end{array}$ & $\begin{array}{c}\text { Strongyloideswes } \\
\text { teri }(\%)\end{array}$ & $\begin{array}{c}\text { Habronema } \\
\text { spp. }(\%)\end{array}$ & $\begin{array}{l}\text { Amphistome } \\
\text { spp. }(\%)\end{array}$ & $\begin{array}{c}\text { Anoplocephala } \\
\text { spp. (\%) }\end{array}$ & $\begin{array}{c}\text { Setariaequ } \\
\text { ina }(\%)\end{array}$ \\
\hline March-16 & 19 & $\begin{array}{c}4 \\
(21.05 \%)\end{array}$ & $\begin{array}{c}3 \\
(15.79 \%)\end{array}$ & $\begin{array}{c}1 \\
(5.26 \%)\end{array}$ & - & - & - & - & - & - \\
\hline April-16 & 22 & $\begin{array}{c}6 \\
(27.27 \%)\end{array}$ & $\begin{array}{c}2 \\
(9.09 \%)\end{array}$ & $\begin{array}{c}1 \\
(4.55 \%)\end{array}$ & $\begin{array}{c}1 \\
(4.55 \%)\end{array}$ & - & - & - & $\begin{array}{c}1 \\
(4.55 \%)\end{array}$ & $\begin{array}{c}1 \\
(4.55 \%)\end{array}$ \\
\hline Мay-16 & 18 & $\begin{array}{c}4 \\
(22.22 \%)\end{array}$ & $\begin{array}{c}2 \\
(11.11 \%)\end{array}$ & $\begin{array}{c}1 \\
(5.55 \%)\end{array}$ & - & - & $\begin{array}{c}1 \\
(5.55 \%)\end{array}$ & - & - & - \\
\hline June-16 & 23 & $\begin{array}{c}5 \\
(21.74 \%)\end{array}$ & $\begin{array}{c}2 \\
(8.69 \%)\end{array}$ & - & - & $\begin{array}{c}1 \\
(4.35 \%)\end{array}$ & $\begin{array}{c}1 \\
(4.35 \%)\end{array}$ & - & - & $\begin{array}{c}1 \\
(4.35 \%)\end{array}$ \\
\hline July-16 & 31 & $\begin{array}{c}11 \\
(35.48 \%)\end{array}$ & $\begin{array}{c}6 \\
(19.35 \%)\end{array}$ & $\begin{array}{c}4 \\
(12.9 \%)\end{array}$ & - & - & - & $\begin{array}{c}1 \\
(3.23 \%)\end{array}$ & - & - \\
\hline Aug.- 16 & 23 & $\begin{array}{c}10 \\
(43.48 \%)\end{array}$ & $\begin{array}{c}5 \\
(21.74 \%)\end{array}$ & $\begin{array}{c}4 \\
(17.39 \%)\end{array}$ & - & $\begin{array}{c}1 \\
(4.35 \%)\end{array}$ & - & - & - & - \\
\hline Sept. -16 & 21 & $\begin{array}{c}9 \\
(42.86 \%)\end{array}$ & $\begin{array}{c}2 \\
(9.52 \%)\end{array}$ & $\begin{array}{c}3 \\
(14.28 \%) \\
\end{array}$ & - & $\begin{array}{c}2 \\
(9.52 \%)\end{array}$ & - & $\begin{array}{c}1 \\
(4.76 \%)\end{array}$ & - & $\begin{array}{c}1 \\
(4.765)\end{array}$ \\
\hline Oct. -16 & 19 & $\begin{array}{c}7 \\
(36.84 \%)\end{array}$ & $\begin{array}{c}1 \\
(5.26 \%)\end{array}$ & $\begin{array}{c}2 \\
(10.53 \%)\end{array}$ & $\begin{array}{c}2 \\
(10.53 \%)\end{array}$ & $\begin{array}{c}1 \\
(5.26 \%)\end{array}$ & - & - & & $\begin{array}{c}1 \\
(5.26 \%)\end{array}$ \\
\hline Nov. -16 & 17 & $\begin{array}{c}6 \\
(35.29 \%)\end{array}$ & $\begin{array}{c}1 \\
(5.88 \%)\end{array}$ & $\begin{array}{c}2 \\
(11.76 \%)\end{array}$ & $\begin{array}{c}1 \\
(5.88 \%)\end{array}$ & $\begin{array}{c}1 \\
(5.88 \%)\end{array}$ & - & - & - & $\begin{array}{c}1 \\
(5.88 \%)\end{array}$ \\
\hline Dec. -16 & 21 & $\begin{array}{c}7 \\
(33.33 \%)\end{array}$ & $\begin{array}{c}2 \\
(9.52 \%)\end{array}$ & $\begin{array}{c}2 \\
(9.52 \%)\end{array}$ & $\begin{array}{c}1 \\
(4.76 \%)\end{array}$ & $\begin{array}{c}1 \\
(4.76 \%)\end{array}$ & - & $\begin{array}{c}1 \\
(4.76 \%)\end{array}$ & - & - \\
\hline Jan. - 17 & 16 & $5(31.25 \%)$ & $\begin{array}{c}2 \\
(12.5 \%)\end{array}$ & $\begin{array}{c}1 \\
(6.25 \%)\end{array}$ & $\begin{array}{c}1 \\
(6.25 \%)\end{array}$ & $\begin{array}{c}1 \\
(6.25 \%)\end{array}$ & - & - & - & - \\
\hline Feb. -17 & 17 & $5(29.41 \%)$ & $\begin{array}{c}1 \\
(5.88 \%)\end{array}$ & $\begin{array}{c}1 \\
(5.88 \%)\end{array}$ & $\begin{array}{c}1 \\
(5.88 \%)\end{array}$ & $\begin{array}{c}1 \\
(5.88 \%)\end{array}$ & - & - & - & $\begin{array}{c}1 \\
(5.88 \%)\end{array}$ \\
\hline Over all & 247 & $\begin{array}{c}79 \\
(31.98 \%)\end{array}$ & $\begin{array}{c}29 \\
(11.74 \%)\end{array}$ & $\begin{array}{c}22 \\
(8.91 \%)\end{array}$ & $\begin{array}{c}7 \\
(2.83 \%)\end{array}$ & $\begin{array}{c}9 \\
(3.64 \%)\end{array}$ & $\begin{array}{c}2 \\
(0.81 \%)\end{array}$ & $\begin{array}{c}3 \\
(1.21 \%)\end{array}$ & $\begin{array}{c}1 \\
(0.40 \%)\end{array}$ & $\begin{array}{c}6 \\
(2.43 \%)\end{array}$ \\
\hline \multicolumn{11}{|c|}{$\chi^{2}=21.94(p=0.01)($ Significant $)$} \\
\hline \multicolumn{11}{|c|}{$(p<0.05=$ significant $)(p>0.05=$ Non significant $)$} \\
\hline
\end{tabular}


Fig.1 Microscopic examination of faecal sample showing ova of Parascaris equorum a.(10x), $b$. $(40 x)$
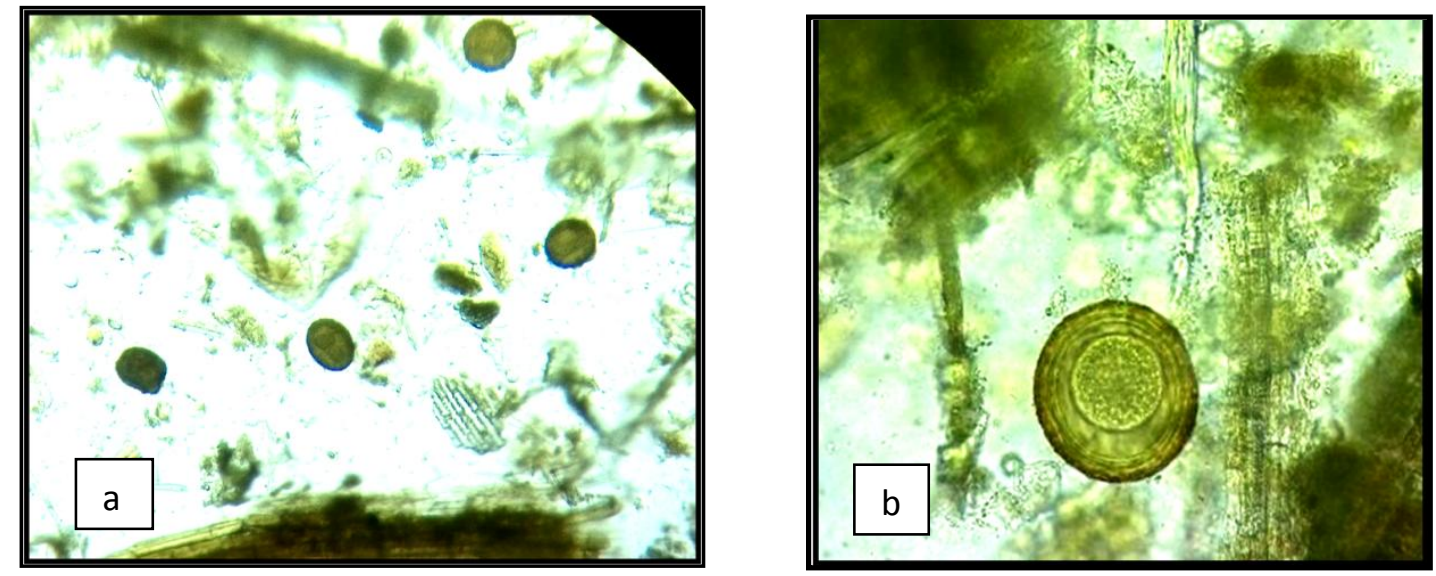

Fig.2 Microscopic examination of faecal sample showing ova of Strongylus spp. (10x)
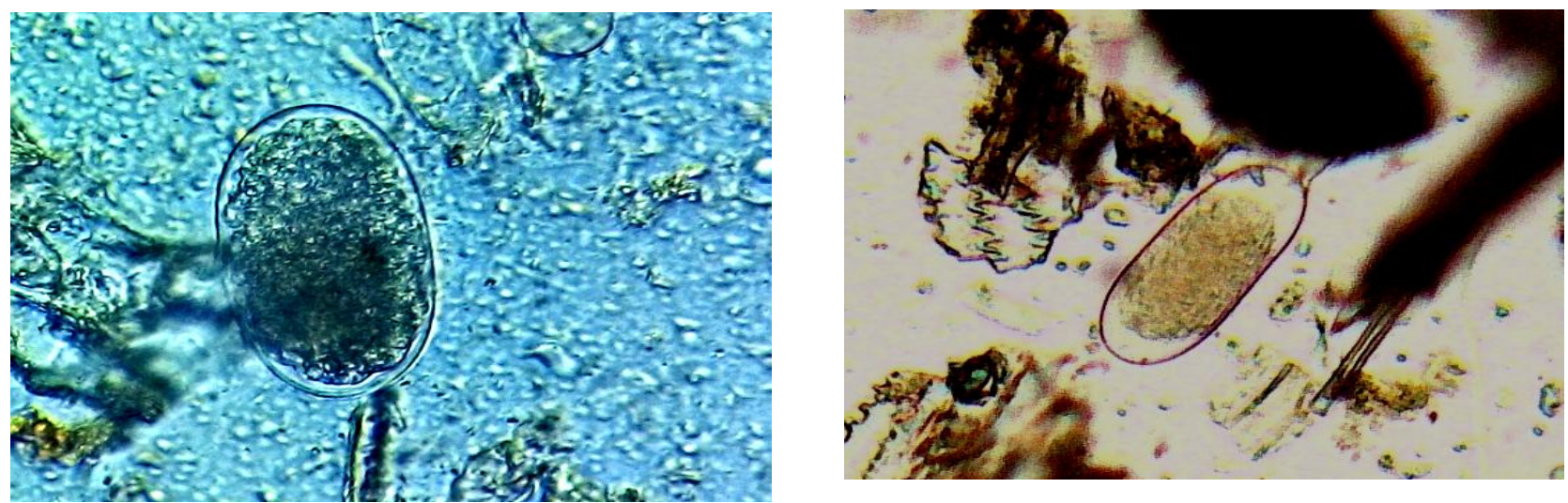

Fig.3 Microscopic examination of faecal sample showing ova of Strongyloides westeri (10x)

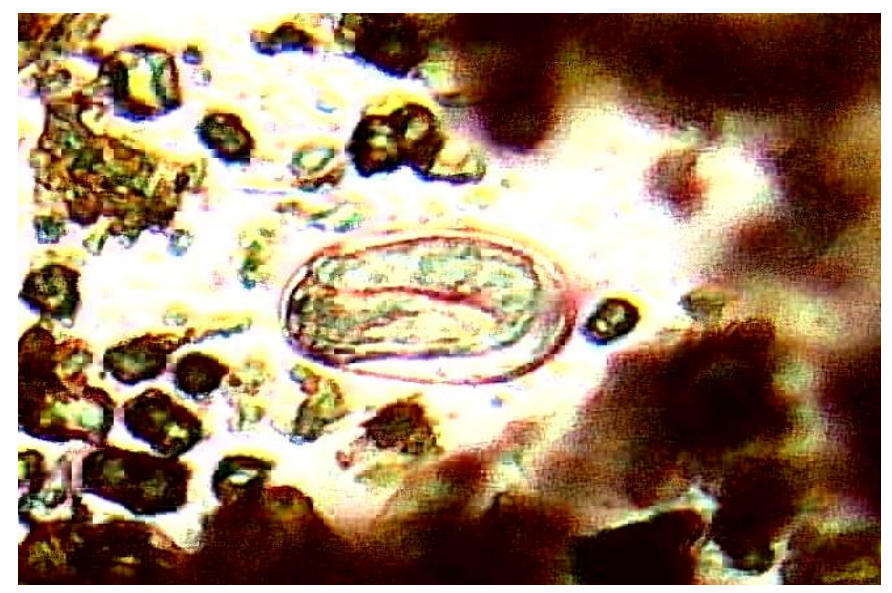


Fig.4 Microscopic examination of faecal sample showing ova of Amphistome spp. (10x)

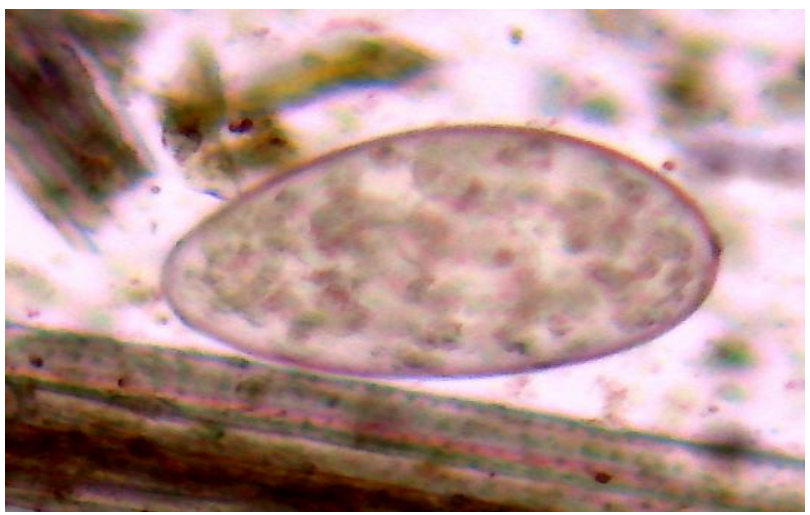

Fig.5 Microscopic examination of faecal sample showing ova of Oxyuris equi a. (10x), b. Ova containing larvae (10x)
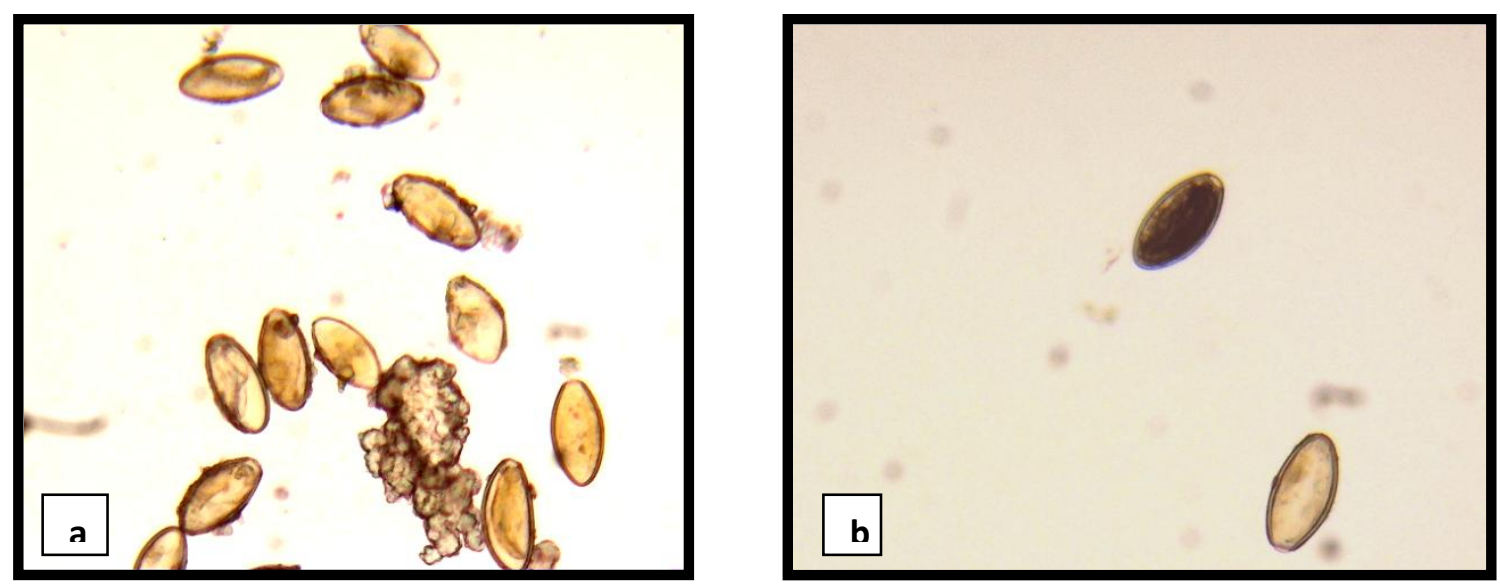

Fig.6 Gross worm of Parascaris equorum
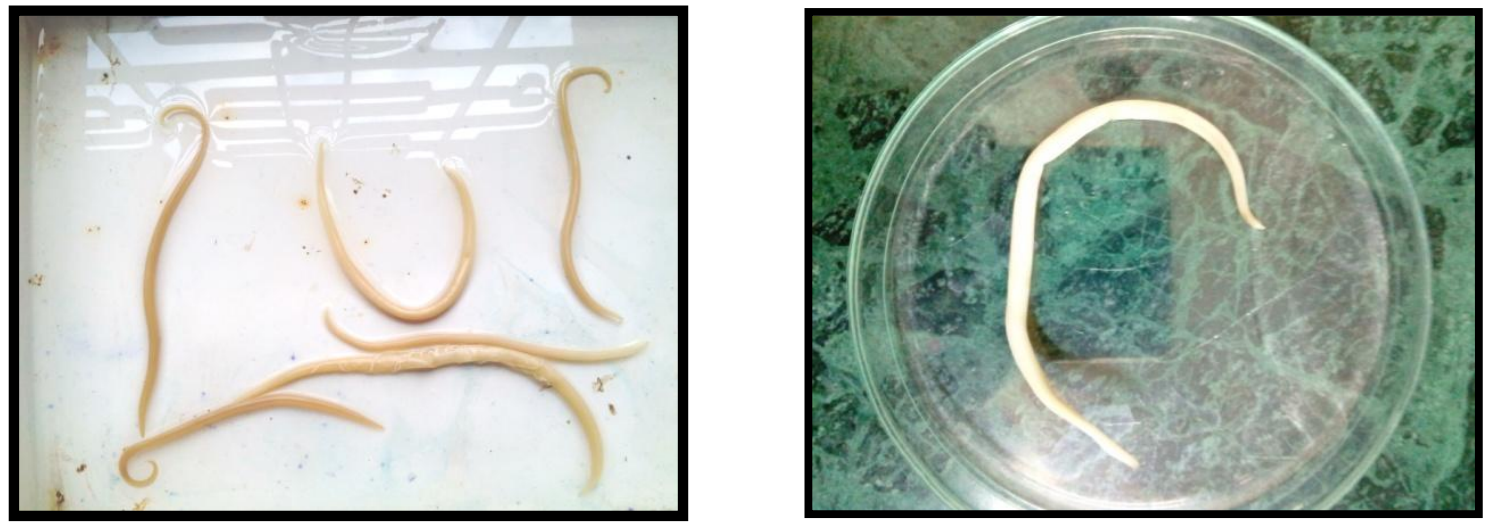
Fig.7 Gross worm of Setaria equina, a. Worm (gross) b. and c. Examination of worm by Steriozoom microscope

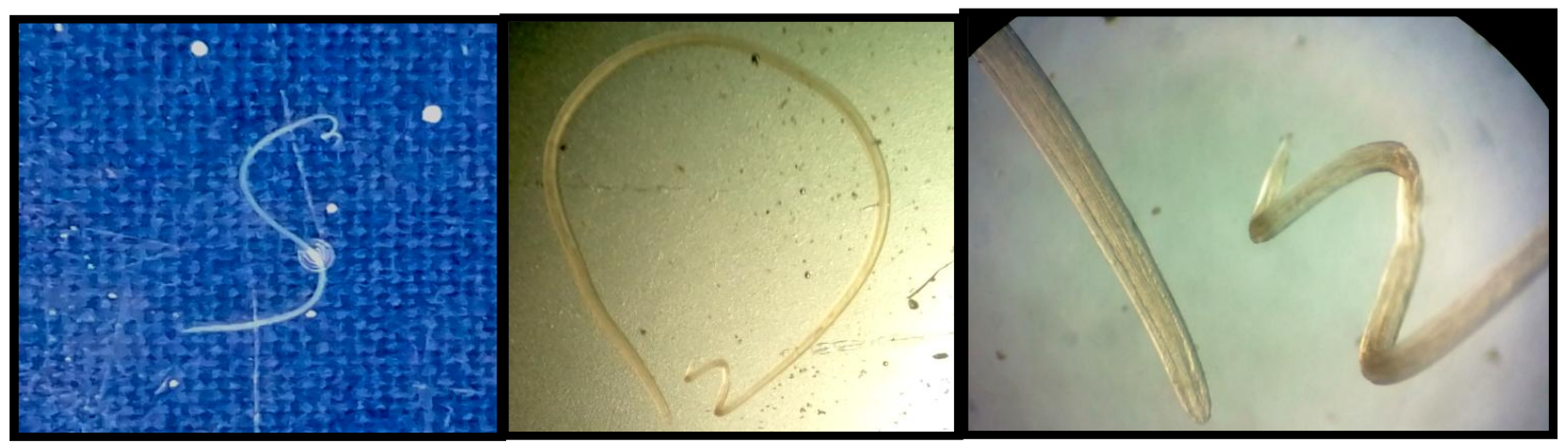

The highest prevalence rate was observed in the month of August (43.48\%) and lowest in the month of March (21.05\%). In the present study higher prevalence occur in the months of August (43.48\%) followed by September $(42.86 \%)$, October $(36.84 \%)$ and July $(35.48 \%)$. Higher prevalence in these months may be due to higher rainfall that favours the suitable environmental conditions for helminthic infection as well as humidity also plays significant role. Optimum temperature is an important factor in the release of larvae from the eggs as well as rainfall in these mentioned months also influences the prevalence of the helminth infection in horses. The higher prevalence of the parasites during the higher rain fall may also be associated due to hygienic problems and water lodges in stables and surrounding field areas. In the August- 2016, due to the changes in climate and sudden rainfall in investigated area, probably the prevalence rate was found highest. The primary factors affecting the development and survival of the eggs and larvae are temperature and moisture. Levine (1977) (4) also stated that maximum development of helminth occurred under constant conditions of temperature and relative humidity. In contrast to present study Parsani et al., (2013) (5) reported seasonally maximum prevalence $(85.3 \%)$ in March and minimum $(65.2 \%)$ in July while in our study maximum prevalence was in August (43.48
$\%)$ and minimum in March (21.05\%). Yadav et al., (2014) (6) reported higher prevalence rate of nematodes infection in horses in April (85\%) and May (70\%) months while in our study higher prevalence was in August (43.48 $\%)$ and September (42.86\%).

The highest prevalence of gastrointestinal helminthosis was noticed in Monsoon followed by Winter and lowest in Summer. The above findings were in accordance with the findings of Ayele et al., (2006)(7) reported that rainy season has encouraged strongyle infection. Singh et al., (2012)(8) reported that season wise intensity of infection was highest in Monsoon (79.35\%) followed by post Monsoon (74.28 \%), Summer $(69.23 \%)$ while it was lowest in winter (59.70 \%). Umar et al., (2013)(9) reported higher prevalence of gastrointestinal parasites in wet season $(39.6 \%)$ than dry season (31.3\%). Matto et al., (2015)(10)reported that the prevalence of gastrointestinal helminthosis is higher in Monsoon (48.57\%) followed by Winter $(38.89 \%)$ and Summer (36\%). As there is optimum required temperature and humidity that favours the development of eggs of gastrointestinal helminths and subsequently development of third stage infective larvae in Monsoon season. Such ambient requirement favours the bionomics of strongyle and other parasitic larvae. 
The occurrence of gastrointestinal helminthosis was more frequently recorded in horses from 6-12 years followed by 12-18 year and lower in 1-6 years by examining faecal samples. A total of 247 faecal samples were collected, out of which 79 faecal samples were found positive with the agewise prevalence of $(33.96 \%)$ in 6-12 years, $(30.85 \%)$ in $12-18$ years and $(29.79 \%)$ in $1-6$ years.

These findings are in accordance with Worku and Afera (2012) (11) who reported that age specific prevalence of the parasites were $9.4 \%, 27.6 \%$ and $15.1 \%$ in young, adult and old horses respectively and however prevalence was found to be statistically significant $(\mathrm{P}<0.05)$. Difference in prevalence of gastrointestinal helminthosis in young, adult and old horses may be due to different grazing pattern of animal and adult animal also get infection from their occupational field areas.

Overall higher sexwise prevalence of gastrointestinal helminthosis was noticed in female and lower in male by examining faecal samples. Female has high percentage (33.04\%) of infection as compare to female $(31.11 \%)$. The present study correlates with Singh et al., (2012) (8) reported that sexwise higher prevalence was recorded in female equines $(75.73 \%)$ as compared to males $(72.30 \%)$. This may also due to the individual hormonal status of male and female.

Breedwise higher prevalence (33.66\%) was found in Kathiawari followed by Marwari (32.14\%) and lowest in Non Descript (Sindhi, Thorough breed, Punjabi etc.) (29.03\%). Breedwise results showed that there was inadequate management and failure of providing hygienic conditions to animals.

In this study for deriving prevalence rate, 247 faecal samples were collected out of which 79 faecal samples were found positive with overall prevalence rate of (31.98\%). Various gastrointestinal helminths have been encountered during the whole study period, viz. Strongylus spp. (11.74\%), Parascaris equorum (8.91\%), Oxyuris equi (2.83\%), Strongyloides westeri. (3.64\%), Habronema spp. (0.81\%), Amphistome spp. (1.21\%), Anoplocephala spp. (0.40\%) and Setaria equina $(2.43 \%)$. Similar findings were shown by Lem et al., (2012)(12), who reported that Strongylus spp. (21.6\%) had the highest prevalence, followed by Parascaris equorum (18.8\%), Oxyuris equi (15.2\%), Cyathostomum spp. (12.6\%), Trichostrongylus axei (10.6\%), Anoplocephala magna (6.3\%), Strongyloides westeri (4.9\%), Habronema spp. (2.8\%) and Triodontophorus spp. (2\%).

Prevalence of Strongylus spp. was found higher in August (21.74\%) and July (19.35\%) months (Table 8). It may be due to optimum temperature and humidity in these months which is favourable for Strongylus spp. larval development and survival in the pasture. Prevalence of Parascaris equorum was found higher in August (17.39\%) and in September (14.28\%) months. Parascaris equorum was found throughout year during study period. It may be due to the inadequate management and unhygienic conditions in the stable and surrounding areas. Prevalence of Strongyloides westeri was consistently seen from August-16 to February-17 and higher in September $(9.52 \%)$ month. This mentioned period is favourable for lifecycle of Strongyloides westeri (optimum warmth and humidity), which enhances the heterogonic cycle. In heterogonic lifecycle first stage larvae rapidly transformed into subsequent larval stages and within 48 hours sexually mature free living males and females occur. Following copulation, the free living female produces eggs which hatch in a few hours and larvae metamorphose to become infective larvae (Soulsby, 1982)(13). 
In conclusion, the present study shows higher prevalence was observed in the months of August (43.48\%) followed by September $(42.86 \%)$, October $(36.84 \%)$ and July $(35.48 \%)$. Higher prevalence in these months might be due to higher rainfall and humidity which provide the suitable environmental conditions for proliferation of helminthic infection.

The present study showed highest seasonal prevalence $(39.36 \%)$ in Monsoon followed by $(32.39 \%)$ in winter and lowest $(23.17 \%)$ in summer in particular season. There was no significant difference ( $p>0.05$ ) in the prevalence of gastrointestinal helminthosis in particular season. Seasonwise positive prevalence percentage was higher in Monsoon (46.84\%) followed by winter $(29.11 \%)$ and summer $(24.05 \%)$. There was significant difference $(p<0.05)$ in the seasonwise positive prevalence percentage of gastrointestinal helminthosis. Overall seasonal prevalence was higher in Monsoon $(14.98 \%)$ followed by winter $(9.31 \%)$ and Summer $(7.69 \%)$. However, there was no significant difference ( $p>0.05)$ in the overall seasonal prevalence of gastrointestinal helminthosis.

In the present study, agewise prevalence was higher in 6-12 years $(33.96 \%)$ followed by $12-18$ years $(30.85 \%)$ and $1-6$ years $(29.79 \%)$ of age. Difference in prevalence of gastrointestinal helminthosis in young, adult and old horses might be due to different grazing pattern of animal and adult animal also get infection from their occupational field areas.

Present study showed that incidence of gastrointestinal helminthosis was higher in females $(33.04 \%)$ as compared to males $(31.11 \%)$. This may also be due to the individual hormonal status of male and female.
According to breed, Kathiawari (33.66\%) showed higher incidence as compared to Marwari (32.14\%) and Non Descript (Sindhi, Thoroughbreed, Punjabi etc.) (29.03\%). Breedwise results showed that there was inadequate management and failure of providing hygienic conditions to the animals.

In the present study, overall prevalence of gastrointestinal helminthosis was found 31.98 $\%$. A significant difference $(\mathrm{p}<0.05)$ was found pertaining to the overall prevalence of gastrointestinal helminthosis in horses.

Various gastrointestinal helminths have been encountered during the entire study period, viz. Strongylus spp. (11.74\%), Parascaris equorum ( $8.91 \%)$, Oxyuris equi (2.83\%), Strongyloides westeri. (3.64\%), Habronema spp. (0.81\%), Amphistome spp. (1.21\%), Anoplocephala spp. (0.40\%) and Setaria equina $(2.43 \%)$.

Gastrointestinal helminthosis has a marked adverse effect on the health status of horses. Season as well as change in the environmental conditions may also play the important role for development of gastrointestinal helminth parasites.

Appropriate adequate management strategies and providing hygienic environment with suitable broad spectrum anthelmintics are the ways to control gastrointestinal helminths of the horses.

\section{Source of funding}

This study was funded by College of Veterinary Science and A. H., AAU, Anand (Gujarat).

\section{Acknowledgement}

The authors are grateful to all the veterinary surgeons that provided samples for the study. 


\section{References}

1. $19^{\text {th }}$ Livestock Census (2012). All India Report. Ministry of Agriculture Department of Animal Husbandry, Dairying and Fisheries, Krishi Bhawan, New Delhi.

2. Donald H. and Bliss, Ph.D. (2000). The Control of Gastro-Intestinal Nematode Parasites in Horses with Emphasis on Reducing Environmental Contamination. "Anew Control Strategy for an Old Problem."Mid America Ag. Res., Verona, WI.

3. Gebreab, F. (1998). Helminth Parasites of Working Equids: The African perspective. Proceedings of the $8^{\text {th }}$ International Conference on Infectious Diseases of equines. Dubai, UAE. 318-324.

4. Levine, N. D. (1977). The influence of weather on the bionomics of the freeliving stage of nematodes. In: Weather and Parasitic Animal Disease, ed. T. E. Gibson, technical note no. 159,51 57.

5. Parsani, H. R., Momin, R. R., Lateef, A., and Das, H. (2013). Studies on gastrointestinal helminths of Equus acinus in North Gujarat, India. Egyptian Journal of Biology, 15(1), 13-20.

6. Yadav, K. S., Shukla, P. C., Gupta, D. K., and Mishra, A. (2014). Prevalence of gastrointestinal nematodes in horses of Jabalpur region. Res. J. Vet. Pract., 2(3), $44-48$.

7. Ayele, G., Feseha, G., Bojia, E., and Joe, A. (2006). Prevalence of gastro- intestinal parasites of donkeys in Dugda Bora District, Ethiopia. Liv. Res. Rural Dev., 18(10), 14-21.

8. Singh, G., Soodan, J. S., Singla, L. D., and Khajuria, J. K. (2012). Epidemiological studies on gastrointestinal helminths in horses and mules. Vet. Practitioner, 13, 2327.

9. Umar, Y. A., Maikaje, D. B., Garba, U. M., and Alhassan, M. A. F. (2013). Prevalence of Gastro-Intestinal Parasites in Horses Used for Cadets Training in Nigeria. J. Vet. Adv., 3(2), 43-48.

10. Matto, T. N., Bharkad, G. P., and Bhat, S. A. (2015). Prevalence of gastrointestinal helminth parasites of equids from organized farms of Mumbai and Pune. J. Parasit. Dis., 39(2), 179-185.

11. Worku, S., and Afera, B. (2012). Prevalence of equine nematodes in and around Kombolcha South Wollo, Ethiopia. Revista Electrónica de Veterinaria, 13(9), 1-13.

12. Lem, M. F., Vincent, K. P., Pone, J. W., and Joseph, T. (2012). Prevalence and intensity of gastro-intestinal helminths in horses in the Sudano-Guinean climatic zone of Cameroon. Trop Parasitol., 2(1), 45-48.

13. Soulsby, E. J. L. (1982). Helminth Arthropods and protozoa of Domesticated Animals ( $7^{\text {th }}$ ed.). The English Language Book Society, Bailliere Tindall, London.

\section{How to cite this article:}

Prakriti Singh, J.J. Hasnani, P.V. Patel, Namrata Singh and Adesh Kumar. 2019. Prevalence of Gastrointestinal Helminthosis in Horses in and around Anand District (Gujarat). Int.J.Curr.Microbiol.App.Sci. 8(04): 33-44. doi: https://doi.org/10.20546/ijcmas.2019.804.004 